\title{
Kalkulowanie finansowych skutków szkody na osobie powstałej na skutek śmierci jednego z żywicieli gospodarstwa domowego
}

Artykuł stanowi propozycję kalkulacji wielkość luki, która powstaje w budżecie gospodarstwa domowego po śmierci jednego z żywicieli. Luka ta pojawia się na skutek utraconych dochodów zmarłego oraz utraconego niefinansowego wkładu osobowego poszkodowanego w gospodarstwo domowe. Jednym ze źródeł finansowania tej luki może być renta dla pośrednio poszkodowanych, tj. osób bliskich zmarłego (małżonka, rodzica, dziecka, rodzeństwa itp.), a także odszkodowanie za znaczne pogorszenie sytuacji życiowej. W wielu krajach Unii Europejskiej osoby, które sq członkami gospodarstwa domowego zmarłego, sq uznawane za poszkodowane na skutek jego śmierci, co w konsekwencji nakłada na sprawcę wypadku obowiqzek zapłaty odszkodowania i zadośćuczynienia na ich rzecz.

Problem kompensacji utraconych dochodów został zilustrowany regulacjami prawnymi i kalkulacjami opartymi na rachunku aktuarialnym - renty terminowe z uwzględnieniem czasu trwania życia. Przedstawione badania dotycza Polski oraz krajów sqsiadujacych. Propozycja kalkulacji utraconego wkładu osobowego została oparta na rencie terminowej pewnej, a kalkulacje - na przykładzie polskiej gospodarki.

Artykuł wpisuje się w szersze badania autorki nad materialnymi konsekwencjami szkód osobowych oraz źródłami ich finansowania.

Słowa kluczowe: szkody osobowe, renta alimentacyjna, odszkodowanie za znaczne pogorszenie sytuacji życiowej, pośrednio poszkodowani.

\section{Wprowadzenie do tematu kompensacji szkód osobowych}

Pojęcie szkody na osobie nie zostało wyraźnie i jednoznacznie zdefiniowane w literaturze przedmiotu. Wynikać to może z wieloaspektowości tego terminu. Łaczy on elementy ekonomii, prawa, ekonomicznej analizy prawa czy matematyki finansoweji aktuarialnej. Niemniej można wskazać opracowania naukowe, 
które dostarczają wiedzy na jego temat ${ }^{1}$. Na użytek niniejszego artykułu zostanie przywołana definicja llony Kwiecień: „Szkoda na osobie może zatem być traktowana jako jedna z postaci szkody, polegająca na naruszeniu dóbr osobistych (szeroko) lub naruszeniu integralności ciała i zdrowia (wạsko) bądź też jako zespół negatywnych następstw związanych z tymi naruszeniami”z. W artykule odwołano się do szerokiego ujęcia szkody, wskazując na konieczność wyceny skutków śmierci jednego z członków gospodarstwa domowego - utraconych dochodów i pogorszenia sytuacji życiowej pozostałych przy życiu bliskich zmarłego. Ze względu na to, że artykuł skupia się na wycenie szkody dla gospodarstwa domowego, czyli odnosi się do prawa związanego z roszczeniami osób bliskich zmarłego, należy wspomnieć o monografii Moniki Wałachowskiej ${ }^{3}$, która szczegółowo przybliża problematykę prawa cywilnego w zakresie odpowiedzialności za szkodę deliktową poniesiona przez pośrednio poszkodowanych.

Za źródła powstania szkód osobowych uznaje się głównie: wypadki komunikacyjne, wypadki przy pracy, wypadki w życiu prywatnym, błędy medyczne oraz choroby zawodowe. Podstawę prawną dla ustalania kompensacji za tego typu szkody stanowi w Polsce Kodeks cywilny, art. 444447. Podobne przepisy znajdują się w innych kodeksach europejskich. Na przykład w niemieckim: § 249-254, § 842-846 BGB (Burgerliches Gesetzbuch z 18 sierpnia 1896 roku); w francuskim: artykuły 1382 Kodeksu cywilnego z dnia 21 marca 1804 roku i artykuł 6 Loiner Badiner oraz w angielskim: dokument Fatal Accident Act i art. 8 Ustawy o prawach człowieka z 1998 roku.

W artykule podkreśla się znaczenie szkód na osobie dla sektora ubezpieczeń, bowiem najczęstszym źródłem finansowania powstałych z ich tytułu strat finansowych są właśnie ubezpieczenia OC, a w szczególności - OC posiadaczy pojazdów mechanicznych. Liczba roszczeń dotyczących uszkodzenia ciała stanowi obecnie mniej niż 13\% wszystkich roszczeń z tytułu ubezpieczenia OC posiadaczy pojazdów mechanicznych, ${ }^{4}$ natomiast wartość tych roszczeń to prawie połowa całkowitych odszkodowań wypłaconych z tytułu tego ubezpieczenia w Europie - w 2013 roku wyniosła ona 48,4\% łącznej kwoty świadczeń i odszkodowania z tytułu ubezpieczenia OC posiadaczy pojazdów mechanicznych. Najwyższy poziom odszkodowań odnotowano we Francji, Hiszpanii i we Włoszech. Średnia wartość roszczenia w 2013 roku w krajach europejskich wynosiła około 16000 euro, dla porównania: 15500 euro w 2012 roku, 14 500 euro w 2011 roku i 13800 euro w roku 2010. Łącznie w latach 2008-2013 średnia wartość szkody majątkowej w Europie wzrosła o około $20 \%{ }^{5}$. Ważne, by mieć na uwadze, że wartości średnie roszczeń w poszczególnych krajach znacznie się różnią, ale co ważniejsze - wciąż rosną ${ }^{6}$. Największe wzrosty

1. Dla przykładu:W. Czachórski, Zobowiqzania. Zarys wykładu, PWN, Warszawa 1994, s. 72; L. Green, The study and teaching of tort low, „Texas Law Review” 1995, vol. 34; T. Karaś, Uwagina temat pojęcia „szkoda” wamerykańskiej teorii prawa, „Studia luridica” 2007, XLVII, s. 113; J.H. WigmoreA general analysis of tort relations, „Harvard Law Review” 1895, vol. 8, s. 378-379.

2. I. Kwiecień, Ekonomiczna analiza dochodzenia roszczeń o zadośćuczynienie za szkody na osobie z ubezpieczeń odpowiedzialności cywilnej, Wydawnictwo Uniwersytetu Ekonomicznego we Wrocławiu, Wrocław 2015, s. 1 ?.

3. M. Wałachowska, Wynagradzanie szkód deliktowych doznanych przez pośrednio poszkodowanych, LexisNexis, Warszawa 2014.

4. European Motor Insurance Markets. Addendum, June 2016, wykres 19, https://www.insuranceeurope.eu/ european-motor-insurance-markets-addendum [dostęp: 24.07.2017].

5. Ibidem, s. 33.

6. Studiując literaturę, można znaleźć opracowania wskazujące źródła (czynniki prawne, społeczne i ekonomiczne] takich tendencji, np. w pracy T. Holzheu, R. Lechner, Commercial liability: a challenge for businesses and their insurers, „Sigma” 2009, no 5. Przy czym podkreśla się, że postawy społeczne mają wśród tych czynników największe znaczenie - por. F. Furedi, Courting Mistrust: The hidden growth of a culture of litigation in Britain; Centre for Policy Studies, London 1999; U. Leimbacher et al., The globalisation of collective redress: Consequences for the insurance industry, Swiss Re, Zurich 2009; R. Enz, T. Holzheu, The economics 
odnotowano w tym okresie w Grecji (55\%), we Włoszech (45\%) i we Francji [25\%]? . Najwyższe średnie roszczenia odnotowano w 2013 roku w Grecji (ok. 33000 euro), Francji (ok. 22000 euro) i Norwegii (ok. 19000 euro). Najniższe zaś w Czechach (ok. 1500 euro), w Turcji (ok. 4000 euro) i w Estonii (ok. 5 000 euro). Analizując te wartości, należy odnotować, że w poszczególnych krajach europejskich systemy odszkodowań w zakresie szkód osobowych są bardzo różne.

Świadczenia z tytułu szkód osobowych nie sa jednak jednorodne. Głównymi składowymi są koszty opieki (w latach 2010-2011 stanowiły one prawie 54\% wszystkich dokonanych płatności), koszty leczenia (16,4\%), utrata zarobków (9,36\%) i zadośćuczynienie za ból i cierpienie (7,32\%). Podobnych informacji dostarcza również opracowanie Munich Re zaprezentowane na rys. 1.

Rysunek 1. Składowe roszczeń z tytułu szkód na osobie w wybranych krajach europejskich w 2013 roku
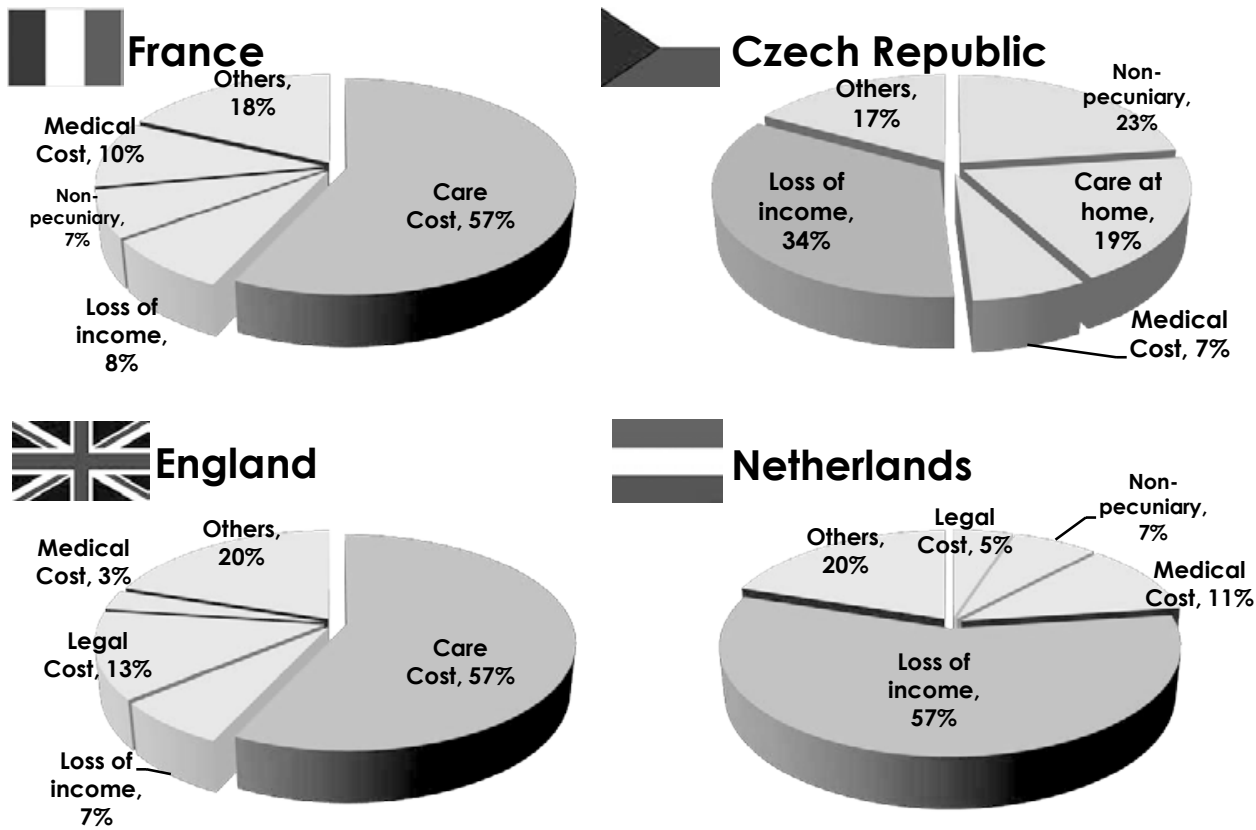

Źródło: J. Yang, S. Reeves, Observations on European Motor Body Injury insurance, 2013.

Jak podkreślają m.in. autorzy najnowszego raportu nt. szkód osobowych wydanego przez Stowarzyszenia ProMotor ${ }^{8}$, badania nad szkodami osobowymi sa utrudnione z powodu nikłej dostępności do dokładniejszych danych na ich temat. W szczególności nie jest znana liczba i wartość

of liability losses - insuring the moving target, „Sigma” 2004, no 6; J.T. Schmidt, Factors Likely to Influence Tort Litigation in the European Union, „The Geneva Papers on Risk and Insurance - Issues and Practice” 2009, $\mathrm{nr}$ 31, s. 304-313; A. Carmignani, S. Giacomelli, Too many lawyers? Litigation in Italian civil courts, „Temi di Discussione" February $2010 \mathrm{nr} 745$.

7. Motor Insurance and Reinsurance. Current Issues and Future Trends, Scor Global P\&C, „Focus” February 2015, s. 34.

8. Current trends in body injury claims in MTPL insurance: 2010-2015, red. J. Monkiewicz, M. Monkiewicz, Promotor, Warszawa 2016. 
poszczególnych typów roszczeń. Nie wiadomo także, jakie elementy składają się na wysokości rent i odszkodowań. Sytuację dodatkowo komplikuje fakt, że zamknięte formalnie sprawy zostały ponownie otwarte w wyniku zmian regulacyjnych lub zmian interpretacyjnych.

\section{Podstawy kalkulacji straty dla gospodarstwa domowego}

Metoda kalkulowania straty, która zaistniała w gospodarstwie domowym, oparta zostanie na treści artykuły 446 k.c. Przepis ten dzieli szkodę dla gospodarstwa domowego na cztery części, graficznie ukazuje to rys. 2 .

Rysunek 2. Składowe szkody dla gospodarstwa domowego po śmierci żywiciela, zgodnie z 446 k.c.

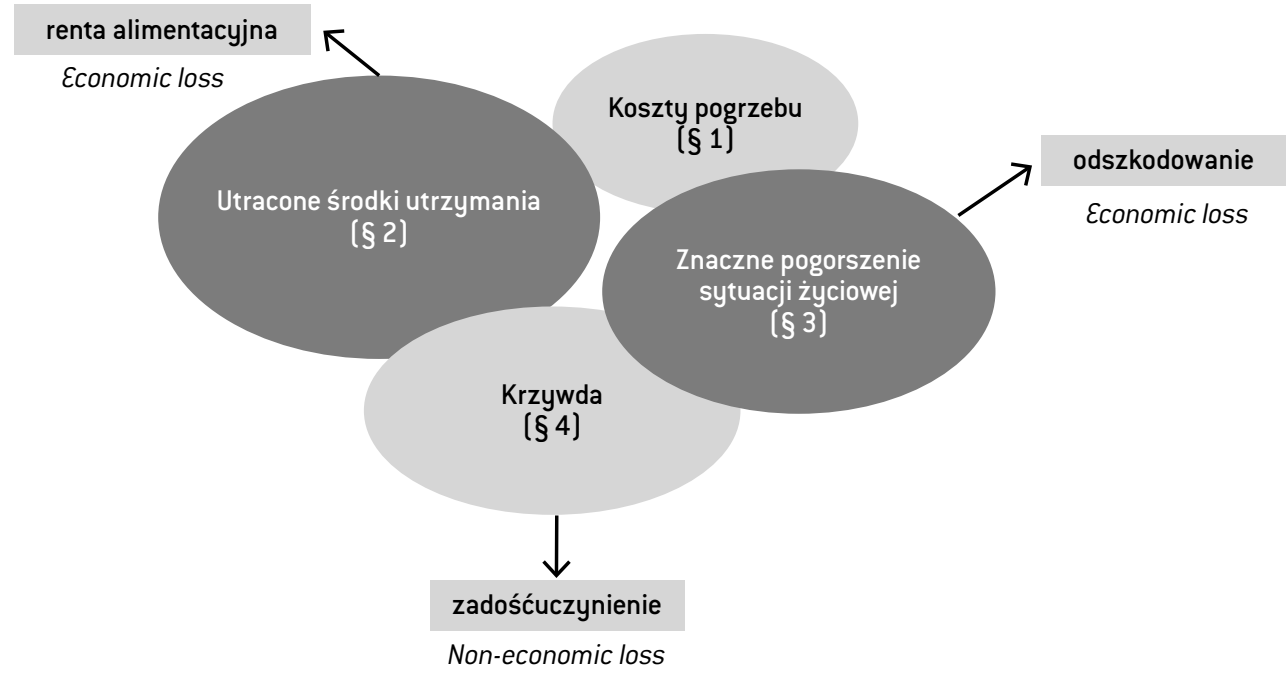

Źródło: oprac. własne.

W tym artykule uwaga zostanie poświęcona dwóm składowym:

1. Rencie dla pośrednio poszkodowanych - rencie alimentacyjnej, która kompensuje utracone dochody.

Specyfiką tej części odszkodowania jest długi horyzont czasowy (renty terminowe - najczęściej do czasu zakończenia edukacji przez dzieci - i renty dożywotnie dla współmałżonków]. Wielkość świadczenia rentowego jest określona odpowiednio do dochodów zmarłego w ujęciu kwot netto. W metodologii ustalania kapitału rentowego (PV renty) zostanie wykorzystany rachunek aktuarialny, czyli uwzględnione zostanie dalsze trwanie życia zgodnie z tablicami trwania życia.

2. Odszkodowaniu, które nie ma charakteru renty, za znaczne pogorszenie się jakości życia pozostałych przy życiu członków rodziny.

Odszkodowanie to powinno być równe wartości obecnej kapitału, który umożliwi:

- kupowanie usług dokonanych w domu przez zmarłego, tj. zastapieniu wkładu osobowego zmarłego w gospodarstwo domowe, 
- pokrycie wydatków poniesionych w gospodarstwie domowym po śmierci członka (np. koszty leczenia traumy czy konsultacji psychologicznych).

Wycena obu składowych musi prowadzić do ustalenia takiej kwoty, za pomocą której możliwe będzie przywrócenie kondycji finansowej i jakości życia bliskich zmarłego przed wypadkiem, z uwzględnieniem realiów środowiska gospodarczego i społecznego, w których funkcjonuje dane gospodarstwo domowe. Wiedza na temat wartości obecnej renty i wysokości kapitału stanowiącego rekompensatę za utracony wkład osobowy jest istotna tak dla płacącego (np. zakładu ubezpieczeń, w przypadku wypłaty renty powstaje konieczność stworzenia rezerwy), jak i dla poszkodowanego ze względu na fakt, że renta zastępowana jest w praktyce jednorazowym świadczeniem [tzw. rentą skapitalizowaną) ${ }^{9}$.

Należy też przywołać niejednorodność w definiowaniu tego, kto jest bliskim ofiary wypadku. Istnieją trzy modele, w których w różny sposób określa się krag osób legitymowanych do odszkodowania ${ }^{10}$. W modelu zamkniętym lista osób uprawnionych jest zamknięta i z góry wyklucza się inne. Taki system występuje np. w Anglii. W modelu pośrednim mowa jest o najbliższym członku rodziny. Takie modele występują w Polsce, Grecji czy Szwecji. W modelu otwartym zupełnie nie określa się bliskiego. Odszkodowanie może uzyskać każda osoba, której więź emocjonalna została naruszona w wyniku śmierci poszkodowanego. Nie musi być to bliski w sensie rodziny. Model otwarty występuje we Francji, Belgii i Hiszpanii.

W kontekście prawa cywilnego ${ }^{11}$ do osób bliskich zalicza się więc małżonka, rodziców i dzieci (własne i przysposobione). Do bliskich zmarłego zalicza się również dziecko poczęte nienarodzone. A często bliskimi są także: rodzeństwo, dziadkowie, wnuki, konkubenci oraz partnerzy tej samej płci. Zatem za główne kryterium można uznać to, czy zmarły tworzył z daną osobą wspólne gospodarstwo domowe.

\section{Utrata dochodów - renta alimentacyjna}

Wraz ze śmiercią osoby, która dostarczała środków finansowych do gospodarstwa domowego, następuje utrata dochodów przez jej osoby bliskie. Dlatego też naturalną konsekwencją poważnych szkód osobowych jest kompensacja utraconych dochodów.

9. Przykładowo we Francji kompensacja utraconych dochodów w $70 \%$ jest wpłacana w postaci świadczenia jednorazowego, za: Scoor Global P\&C, Motor Third Party Liability: Analysis of Serious Bodily Injury compensation from a European perspective, June 2013.

10. Więcej informacji na temat kręgu podmiotowego uprawnionych do odszkodowania czy zadośćuczynienia po śmierci bliskiego w: M. Wałachowska, Wynagradzanie szkód deliktowych doznanych przez pośrednio poszkodowanych, LexisNexis, Warszawa 2014, s. 61-81.

11. Należy podkreślić, że inaczej pojęcie osób bliskich rozumiane jest na przykład przez systemy społeczne. Przykładowo w Polsce wśród osób uprawnionych do renty rodzinnej z FUS (art. 67 ustawy z dnia 17 grudnia 1998 r. o emeryturach i rentach z Funduszu Ubezpieczeń Społecznych, Dz. U. 2016, poz. 2036) znajdują się tylko: dzieci własne, dzieci drugiego małżonka oraz dzieci przysposobione; przyjęte na wychowanie i utrzymanie przed osiągnięciem pełnoletności wnuki, rodzeństwo i inne dzieci, z wyłączeniem dzieci przyjętych na wychowanie i utrzymanie w ramach rodziny zastępczej lub rodzinnego domu dziecka; małżonek (wdowa i wdowiec); rodzice. 
Najbardziej naturalnym powiązaniem jest łożenie przez rodziców na utrzymanie dzieci (własne, przysposobione oraz dzieci, którym przyznano alimenty). Różne są przepisy w poszczególnych państwach co do czasu i zakresu finansowych zobowiązań poszczególnych członków rodziny względem siebie. Najczęściej rodzice mają obowiązek zapewnić utrzymanie dzieciom do momentu osiągnięcia przez nie pełnoletniości, tj. do ukończenia 18 lat, z wyjątkiem przypadków, gdy dziecko jest niezdolne do pracy z powodu kalectwa, wskutek czego uważa się, że nie osiągnęło ono pełnoletniości. Ponadto obowiązek zapewnienia utrzymania spoczywający na rodzicu wobec dziecka nie wygasa z chwilą osiagnnięcia przez dziecko pełnoletniości, jeżeli dziecko nadal uczy się w trybie dziennym w szkole średniej, studiuje na uczelni lub uczy się w szkole zawodowej. Wiek, do którego rodzice winni łożyć na edukację, jest różny w różnych krajach. Przykładowo w Holandii jest to 20 lat, w Irlandii - 23 lata, na Litwie - 24 lata, w Polsce - 25 lat. Z kolei w Luksemburgu nie ma rozszerzenia czasu odpowiedzialności rodzica ponad wiek 18 lat, a w Niemczach i we Włoszech czas ten jest nieograniczony (rodzice muszą utrzymywać zarówno dzieci małoletnie, jak i te, które osiągnęły pełnoletniość, dopóki nie uniezależnią się one finansowo, nie jest to jednak wyrażone wiekiem).

Drugą naturalną relacją finansową jest wspólnota majątkowa małżonków. Nie występuje tu ograniczenie czasowe.

Kolejną relację stanowi przejęcie przez dzieci obowiązku alimentacyjnego na rzecz rodziców, w sytuacji gdy będą oni w starszym wieku. Relacja ta ma charakter nieformalny i również nie jest ograniczona wiekiem.

Mogą też wystapić jeszcze inne relacje finansowe o charakterze dobrowolnym, np. wnuków względem dziadków, czy rodzeństwa względem siebie. Jednak nie mogą one być tylko prawdopodobne, ale musiały istnieć przed wystapieniem szkody osobowej i śmierci osoby płacącej.

Najczęstszym sposobem kompensacji utraconych dochodów jest przyznanie renty - czasowej (dla dzieci) lub dożywotniej (dla małżonka i rodziców). Wysokość takiej renty jest zależna od formy (ustalona prawnie lub dobrowolna), w jakiej wcześniej funkcjonowało utracone finansowanie. Jeśli były to alimenty przyznane sadownie, pozostają w tej samej wysokości. Natomiast jeśli było to świadczenie wynikające z przebywania w jednym gospodarstwie domowym, nie ma jednoznacznej odpowiedzi, jaka ma być wysokość świadczenia.

Przed ustaleniem wysokości dochodu, który utraciło gospodarstwo domowe po śmierci ofiary wypadku, należy pomniejszyć dochód netto zmarłego o część, którą ofiara wypadku sama konsumowała. W teorii ubezpieczeń przyjmuje się że konsumpcja własna czy też koszty samoutrzymania ${ }^{12}$ wynoszą około 30\% dochodu przynoszonego przez daną osobę do gospodarstwa domowego. W polskim systemie ubezpieczeń społecznych kształtuje się na poziomie od 5 do 15\% dochodu. Na użytek tego artykułu przyjęto poziom $20 \%$.

Można przyjąc następujący model do wyliczenia wartości obecnej renty dla dwóch głównych kategorii relacji finansowych występujacych w gospodarstwach domowych - dla współmałżonka $\left(P V_{M}\right.$ z płatnością w wysokości $\left.A_{M}\right)$ i dla dzieci $\left(P V_{c}\right.$ z płatnością w wysokości $\left.A_{C}\right)$.

Płatności dla małżonka i dzieci (o ile nie mają wysokości ustalonej sądowo) są równe i wynoszą:

$$
A_{M}=A_{C}=\frac{0,8 \times \text { dochód netto zmarłego }}{N_{C}+1}
$$

Gdzie $N_{c}$ odpowiada liczbie uprawnionych dzieci.

12. Autorka pracuje obecnie nad własnym badaniem poziomu tej kategorii kosztów dla gospodarstw domowych w Polsce i ogólniej w krajach UE. 
Wartość obecną renty dla żyjącego małżonka można zatem wyznaczyć w następujący sposób. Jest to renta życiowa (aktuarialna), dożywotnia. Model uwzględnia fakt, że po przejściu na emeryturę osoba zmarła przekazywałaby na rzecz gospodarstwa domowego dochód w wysokości niższej (przyjęto więc w modelu stopę zastapienia dla poszczególnych krajów).

$P V_{M}=\sum_{k=0}^{x_{a}-x}(1+i)^{k} v^{k}{ }_{k} p_{x_{m}} A_{M}+\sum_{k=x_{a}-x+1}^{\omega}(1+i)^{k} v^{k}{ }_{k} p_{x_{m}}\left(r_{r e p} A_{M}\right)$

$P V_{M}$ - wartość obecna renty dla żyjącego małżonka

$A_{M}$ - wysokość jednej płatności dla żyjącego małżonka

$x_{m}$ - wiek współmałżonka w chwili śmierci ofiary wypadku

$x_{a}=$ wiek emerytalny $w$ danym kraju $-x$ - czyli lata aktywności zawodowej osoby zmarłej

$x$ - wiek zmarłego w chwili śmierci

${ }_{k} p_{x_{m}}$ - prawdopodobieństwo dożycia przez żyjacego małżonka do momentu wypłaty kolejnej płat-

ności rentowej

$\omega$ - maksymalny czas życia [obecnie 110 lat)

$r_{\text {rep }}$ - stopa zastapienia w danym kraju

Kalkulując rentę alimentacyjną dla dziecka, posłużono się aktualną rentą życiową, terminowạ. Wyliczona jest ona na te lata, w których zmarły rodzic zgodnie z normą prawną danego kraju łożyłby na dziecko.

$P V_{c_{i}}=\sum_{k=0}^{x_{o_{i}}-x_{c_{c_{i}}}}(1+i)^{k} v^{k}{ }_{k} p_{x_{c_{i}}} A_{c}$

$P V_{c_{i}}$ - wartość obecna renty dla $i$-tego dziecka

$A_{c}$ - wysokość jednej płatności dla żyjącego małżonka

$x_{c_{i}}$ - wiek i-tego dziecka w chwili śmierci ofiary wypadku (rodzica)

$x_{o_{i}}$ - wiek, do którego dziecko winno otrzymywać świadczenie od rodziców

${ }_{k} p_{x_{c_{i}}}$ - prawdopodobieństwo dożycia przez $i$-te dziecko do momentu wypłaty kolejnej płatności

Ale w przypadku dziecka z niepełnosprawnością świadczenie jest dożywotnie i wtedy powinno, podobnie jak dla małżonka, uwzględniać czas przejścia na emeryturę osoby zmarłej.

$P V_{K}=\sum_{k=0}^{x_{a}-x}(1+i)^{k} v^{k}{ }_{k} p_{C_{i}} A_{C}+\sum_{k=x_{a}-x+1}^{\omega}(1+i)^{k} v^{k}{ }_{k} p_{C_{i}}\left(r_{r e p} A_{C}\right)$

Zatem wartość obecna kapitału potrzebnego do pokrycia łącznej straty dochodów dla gospodarstwa domowego (przy założeniu, że małżonek i dzieci pochodzą z jednego gospodarstwa domowego] może być wyrażona wzorem: 
$P V=P V_{M}+\sum_{i=1}^{N_{c}} P V_{c_{i}}$

Jako ilustrację dla tej metodologii przedstawiony zostanie przykład.

Na skutek wypadku umiera 35-letni Jan. Dochody Jana to średnia krajowa. Jan miał pracować do 70. roku życia.

Po śmierci Jana uprawnieni do odszkodowania za utracone dochody są:

- 32-letnia Maria - żona

- 7-letni Wojtek - syn

- 5-letni Marek - syn (niepełnosprawny)

- 2-letnia Wiktoria - córka.

Dodatkowe założenia: A - kompensacja do 18. roku życia; B - kompensacja do 25. roku życia dla dzieci. Ponieważ jedno z dzieci jest niepełnosprawne -świadczenie na jego rzecz jest dożywotne. Wysokość średnich wynagrodzeń w poszczególnych krajach oraz stóp zastapienia przyjęto za Eurostatem, a tablice trwania życia pochodzą z mortality.org (dla 2014).

Kalkulacje przeprowadzono dla Polski i krajów sąsiadujących z Polską - Niemiec, Czech, Słowacji, Ukrainy, Białorusi i Litwy. W kalkulacji przyjęto następujące założenia:

- świadczenia sa przyznawane raz w roku, z góry, założenie to wynika z faktu, że tablice trwania życia zawieraja prawdopodobieństwa dożycia kolejnych pełnych lat, ale można je łatwo znieść, stosując założenie o jednorodności rozkładu zgonów, założenie o stałym natężeniu umieralności czy też założenie Balducciego ${ }^{13}$;

- prawdopodobieństwa przeżycia przyjęto za tablicami trwania życia za rok 2014 (za portalem mortality.org), a w przypadku dwóch krajów (Ukraina i Litwa) za rok 2013. Przyjęto osobne tablice dla kobiet i mężczyzn;

- do indeksacji rent przyjęto przeciętna (w okresie 10 lat - od 2005 do 2014) stopę inflacji w każdym kraju (tab. 1.). Jednak dla Ukrainy i Białorusi ze względu na bardzo wysoki poziom średniej inflacji przyjęto $5 \%$;

- za stopę dyskonta przyjęto stopę 10-letnich obligacji skarbowych, tj. 1,44\%.

Tablica 1. Wartości ekonomiczne uwzględnione w kalkulacji

\begin{tabular}{|l|c|c|c|c|c|c|c|}
\hline & BY & CZ & DE & LT & PL & SK & UA \\
\hline Inflacja (\%) & $17,5^{*}$ & 2,21 & 1,71 & 3,71 & 2,53 & 2,36 & $16,5^{*}$ \\
\hline Średnie roczne wynagrodzenie (Euro) & 3965 & 10689 & 28980 & 7476 & 9615 & 9632 & 2200 \\
\hline Stopa zastapienia & 0,56 & 0,55 & 0,45 & 0,45 & 0,63 & 0,62 & 0,56 \\
\hline
\end{tabular}

* wielkość zredukowana do wartości 5\%

Źródło: oprac. własne na podst. danych z Eurostatu.

Zawarte w tab. 2. oraz zilustrowane na rys. 3. wyniki obliczeń pokazuja, że w przypadku trzyosobowej rodziny z jednym niepełnosprawnym dzieckiem strata, która wynika dla gospodarstwa

13. Więcej w: N.L. Bowers, H.U. Gerber, J.C. Hickman, D.A. Jones, C.J. Nesbitt, Actuarial Mathematics, The Society of Actuaries, Itasca 1986. 
domowego z tytułu utraconych dochodów, wynosi około 30-krotność rocznego dochodu zmarłego (ostatnia kolumna tab. 2.). W ocenie autorki jest to znacząca strata majątkowa, która powinno się kalkulować z należytą starannością. Nominalna wartość tej straty różni się znacząco w poszczególnych państwach bowiem kształtuja ja dwa różne czynniki: wysokość średniego wynagrodzenia i długość życia. Ponadto wartości otrzymane dla Białorusi oraz Ukrainy są spotęgowane (ok. 60-krotność średniego wynagrodzenia) przez fakt przyjęcia wysokiego poziomu indeksacji.

Tablica 2. Wartości obecne rent za utracone dochody

\begin{tabular}{|c|c|c|c|c|c|c|}
\hline & PV Maria & PV Tomasz* & PV Marek & PV Wiktoria* & PV łączne* & Relacja \\
\hline BY & $82.343,67$ & $\begin{array}{c}34273,09 \\
55317,46\end{array}$ & 117066,97 & $\begin{array}{l}17 \text { 136,54 } \\
27658,73\end{array}$ & $\begin{array}{l}250820,27 \\
282386,83\end{array}$ & $\begin{array}{l}63,26 \\
71,22\end{array}$ \\
\hline$C Z$ & $112.834,92$ & $\begin{array}{l}26030,16 \\
42126,83\end{array}$ & 137026,89 & $\begin{array}{l}37480,65 \\
54130,20\end{array}$ & $\begin{array}{l}313372,62 \\
346118,84\end{array}$ & $\begin{array}{l}29,32 \\
32,38\end{array}$ \\
\hline $\mathrm{DE}$ & $256.994,65$ & $\begin{array}{c}69358,72 \\
110769,74\end{array}$ & 305943,25 & $\begin{array}{l}335699,66 \\
971660,05\end{array}$ & $\begin{array}{c}967996,28 \\
1645367,69\end{array}$ & $\begin{array}{l}33,40 \\
56,78\end{array}$ \\
\hline LT & $104.412,75$ & $\begin{array}{l}19582,88 \\
33569,38\end{array}$ & 128933,23 & $\begin{array}{l}29380,43 \\
45028,56\end{array}$ & $\begin{array}{l}282309,29 \\
311943,92\end{array}$ & $\begin{array}{l}37,76 \\
41,73\end{array}$ \\
\hline PL & $113.899,57$ & $\begin{array}{r}23871,16 \\
39223,88 \\
\end{array}$ & 140324,51 & $\begin{array}{l}34744,44 \\
50955,37 \\
\end{array}$ & $\begin{array}{l}312839,68 \\
344403,33 \\
\end{array}$ & $\begin{array}{l}32,54 \\
35,82 \\
\end{array}$ \\
\hline SK & $106.830,36$ & $\begin{array}{l}23723,99 \\
38748,02\end{array}$ & 132962,92 & $\begin{array}{l}37579,36 \\
57375,08\end{array}$ & $\begin{array}{l}301096,63 \\
335916,38\end{array}$ & $\begin{array}{l}31,26 \\
34,88\end{array}$ \\
\hline UA & $43.392,40$ & $\begin{array}{c}6113,51 \\
11012,53 \\
\end{array}$ & 63419,78 & $\begin{array}{l}9506,24 \\
15337,74 \\
\end{array}$ & $\begin{array}{l}122431,93 \\
133162,45\end{array}$ & $\begin{array}{l}55,65 \\
60,53 \\
\end{array}$ \\
\hline
\end{tabular}

Źródło: obliczenia własne.

Rysunek 3. Wartości obecne łącznych rent za utracone dochody dla przykładowego gospodarstwa domowego w wybranych krajach

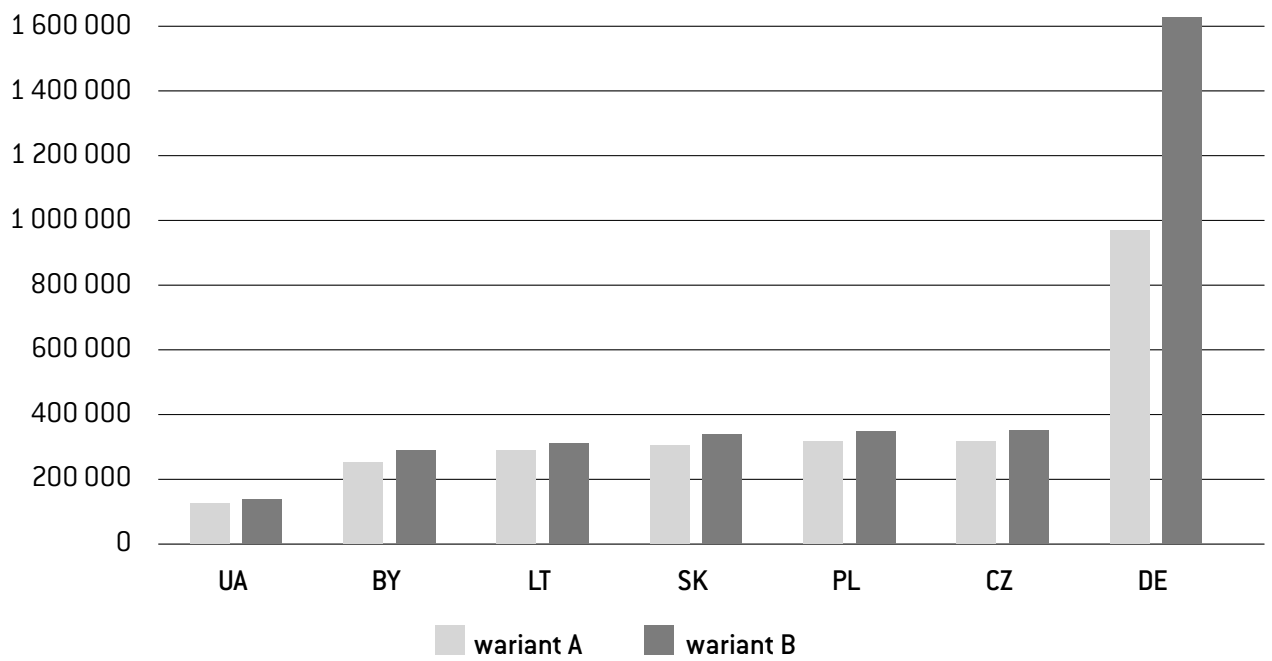

Źródło: oprac. własne. 


\section{Znaczne pogorszenie sytuacji życiowej - odszkodowanie}

Oprócz utraconych dochodów gospodarstwo domowe po śmierci ofiary wypadku traci też niemajątkowy wkład wnoszony przez zmarłego ${ }^{14}$. Część ze składowych tego wkładu jest mierzalna i możliwa do zastapienia poprzez kupienie ich na rynku, część jest bądź niemierzalna bądź niezastępowalna.

Przykładami rzeczy mierzalnych i potencjalnie możliwymi do zastapienia (w nawiasach podano propozycje usług, które moga zastapić poszczególne składowe) są:

- prace domowe (zatrudnienie gosposi),

- opieka nad dziećmi (zatrudnienie niani),

- dowóz dzieci do szkoły czy na inne zajęcia dodatkowe (wynajęcia taksówki),

- odrabianie lekcji z dziećmi (kupienie korepetycji),

- wsparcie psychiczne dzieci w rozmowach (odbycie spotkań z psychologiem),

- ewentualne darmowe prace zgodnie z zawodem, np. mechanik samochodowy za darmo naprawiał auto rodzinne, lekarz leczył za darmo (kupienie usługi na zewnątrz, ale tylko część dot. pracy człowieka, czyli około $40 \%$ ceny usługi to strata rodziny, bo materiały kupiono by i tak],

- przynależność do ubezpieczeń społecznych lub pakietu ubezpieczenia medycznego jako benefit z pracy (samodzielne kupienie takiego ubezpieczenia),

- nauczenie dziecka pewnych czynności, które samemu się umie, np.: pływania, jazdy na nartach, gry na instrumentach (zakup kursu uczącego danej umiejętności).

Wartość straty, która zaistniała w gospodarstwie domowym, może być oszacowana jako suma wartości obecnych strumieni finansowych potrzebnych do kupienia utraconego wkładu osobowego (ujęcie szersze, uwzględniajace nie tylko prace domowe, ale też związane częściowo z relacjami tworzonymi ze zmarłym]. Kalkulacje takie są zbliżone do rachunków prowadzonych w makroskali, a mianowicie rachunków związanych z wycena produkcji domowej ${ }^{15}$, rachunków satelitarnych ${ }^{16}$ czy też ustalania kosztów społecznych wypadków drogowych ${ }^{17}$.

14. Wielkość utraconych świadczeń w naturze w postaci wkładu w utrzymanie stanowi część straty i podlega kompensowaniu np. w Niemczech. Więcej można znaleźć na ten temat w specjalnym numerze "Wiadomości Ubezpieczeniowych" z roku 2010, Zadośćuczynienie po nowelizacji art. 446 Kodeksu cywilnego na tle doświadczeń europejskich, https://piu.org.pl/public/upload/ibrowser/zadoscuczynienie_WU.pdf [dostęp: 25.07.2017].

15. Więcej w: I. Błaszczak-Przybycińska, Produkcja gospodarstw domowych jako czynnik dochodotwórczy, „Monografie i Opracowania” 2008, nr 553, Oficyna Wydawnicza SGH, Warszawa 2008; M. Tomczuk, Wycena wartości prac domowych w rodzinach w Polsce, [w:] K. Stepkowska, J. Stepkowska [red.], Instytucja rodziny wczoraj i dziś. Perspektywa interdyscyplinarna. Tom. 1. Między prawem i rynkiem, Politechnika Lubelska, Lublin 2012, s. 96-103.

16. Więcej przykładowo w: M. Marszałek, Rachunek produkcji domowej w Polsce w koncepcji systemy statystyki społecznej, Oficyna Wydawnicza SGH, Warszawa 2015.

17. Więcej w raportach i opracowaniach Krajowej Rady Bezpieczeństwa Ruchu Drogowego, przykładowo w: A. Jaździk-Osmólska, Wycena kosztów wypadków i kolizji drogowych na sieci dróg w Polsce na koniec roku 2015, z wyodrębnieniem średnich kosztów społeczno-ekonomicznych wypadków na transeuropejskiej sieci transportowej, Krajowa Rada Bezpieczeństwa Ruchu Drogowego, Warszawa 2016. 
W szacowaniu poziomu takiej szkody posłużyć się można danymi Głównego Urzędu Statystycznego nt. budżetu czasu gospodarstw domowych ${ }^{18}$. Badania te wskazuja, ile czasu poszczególne osobowy (indywidualnie) poświęcają na rożne aktywności (główne kategorie to: potrzeby fizjologiczne, praca zawodowa, nauka, zajęcia i prace domowe, dobrowolna praca w organizacjach i poza nimi - wolontariat, życie towarzyskie i rozrywki, uczestnictwo w sporcie i rekreacji, zamiłowania osobiste, korzystanie z środków masowego przekazu, dojazdy i dojścia oraz inne niemierzalne czynności]. W raporcie wskazuje się na różnice w zaangażowaniu kobiet i mężczyzn, ale także zależnie od tego, czy dana osoba tworzy jedno- czy wieloosobowe gospodarstwo domowe. Znaczenie ma również, czy wieloosobowe gospodarstwo domowe to małżeństwo bez dzieci, czy też z dziećmi. Wpływ na zaangażowanie w prace domowe ma również wiek najmłodszego z dzieci (od 0 do 6 lat oraz od 7 do 17 lat).

Zatem w tej kalkulacji można posłużyć się rosnąca rentą pewną, terminową, o płatnościach rocznych z góry.

$P V=\sum_{i=1}^{K} P V_{N_{i}}$

$P V_{N_{i}}=A_{i} q \frac{q^{n_{i}}-d^{n_{i}}}{q-d} \times \frac{1}{q^{n_{i}}}$

$K$ - liczba usług, które gospodarstwo domowe zakupi celem zastapienia wkładu osobowego po zmarłym ${ }^{19}$

$A_{i}$ - wysokość kapitału potrzebnego do zakupienia $i$-tej usługi w pierwszym roku (w kolejnych latach kapitał ten będzie wzrastał o inflację)

$n_{i}$ - liczba lat, przez które gospodarstwo domowe będzie kupowało $i$-tą usługę

$P V_{N_{i}}$ - wartość obecna kapitału potrzebnego na zakup $i$-tej usługi

$q=1+r ; r$ - stopa dyskonta

$d=1+i ; i-$ stopa inflacji

llustracją do powyższych rozważań niech będą modelowe obliczenia, przeprowadzone tylko dla Polski. Mają one na celu pokazanie możliwości skalkulowania rozmiaru szkody związanej z pogorszeniem się sytuacji życiowej rodziny oraz wskazanie wartości tej szkody w oparciu o wartości średnie dla Polski. Ogólne założenia dot. gospodarstwa domowego są takie, jak w przykładzie wcześniejszym. Ponadto przyjmijmy, ze Jan miał własny warsztat samochodowy. Naprawiał więc za darmo dwa samochody należące do rodziny. Nie jeździł do pracy (warsztat był przy domu). To on zawoził dzieci do szkoły i zapewniał im opiekę po szkole. On też wykonywał część prac domowych. Zajmował się również ogrodem. Rodzina była ubezpieczona „na jego konto” - ubezpieczenie społeczne, zdrowotne.

18. Najnowszy raport GUS Budżet czasu ludności w 2013 r. Część // dostępny na stronie: http://stat.gov.pl/obszary-tematyczne/warunki-zycia/dochody-wydatki-i-warunki-zycia-ludnosci/budzet-czasu-ludnosci-w-2013-r-czesc-ii-wraz-z-czescia-i,19,2.html [dostęp: 25.07.2017] .

19. Przy czym okresy te nie sa jednorodne, zgodnie z uwagami wcześniejszymi w oparciu o badania GUS. 
W pierwszym etapie należy zidentyfikować utracone aktywności zmarłego, które można zastapić usługami kupionymi na rynku. Należy również ocenić, jaki czas poświęcał zmarły na dana czynność. A następnie znaleźć substytucyjną usługę na rynku i jej cenę. W przykładzie posłużono się wartościami przeciętnymi dla Polski, głównie na bazie opracowań GUS.

Do listy utraconych aktywności zaliczono ${ }^{20}$ :

I. opiekę nad dziećmi,

II. przygotowywanie posiłków,

III. sprzątanie, dbanie o odzież i robienie zakupów,

IV. pracę w ogrodzie,

V. drobne naprawy,

VI. rozmowy z dziećmi,

VII. odrabianie lekcji z dziećmi,

VIII. odwożenie dzieci do szkoły,

IX. pracę przy samochodach rodziny,

$X$. ubezpieczenie zdrowotne.

Jak wspomniano, w ustalaniu liczby godzin w ciaggu roku, które zmarły poświęcał na dana czynność, posłużono się opracowaniem GUS. Czas utraconego życia ofiary wypadku podzielono na podokresy, zgodnie z założeniami badania GUS. W omawianym przykładzie będą to: 4 lata (kiedy to rodzina zalicza się do kategorii - małżeństwo z najmłodszym dzieckiem do 6 lat), kolejne 11 lat (kiedy rodzina zalicza się do kategorii - małżeństwo z najmłodszym dzieckiem 6-17 lat), kolejne 18 lat (mężczyzna do 65 lat) oraz kolejne 9 lat (mężczyzna powyżej 65 lat, ale do poziomu 74 lat zgodnie z długością życia mężczyzn w Polsce w roku 2014²1.

Tablica 3. Liczba godzin, którą rocznie w poszczególnych okresach poświęcał zmarły na poszczególne aktywności (Ad. I-VI)

\begin{tabular}{|c|c|c|c|c|}
\hline & 4 lata & 11 lat & 18 lat & 9 lat \\
\hline I & 734 & 400 & 686 & 601 \\
\hline II & 297 & 352 & 376 & 461 \\
\hline III & 862 & 1007 & 1098 & 1226 \\
\hline IV & 394 & 479 & 631 & 734 \\
\hline$V$ & 831 & 837 & 813 & 637 \\
\hline $\mathrm{VI}$ & 534 & 564 & 334 & 273 \\
\hline
\end{tabular}

Źródło: oprac. własne na podst. tab. 3., 6., 9. oraz 13c w: Budżet czasu ludności...

Znając wymiar godzinowy poszczególnych aktywności, należy poszukać usług będących ich substytutami oraz wartości tych usług. W tab. 4. wskazano listę usług subsydiujacych poszczególne

20. W tworzeniu tej listy kierowano się kategoriami znajdującymi się w opracowanych GUS-u. Sześć pierwszych kategorii jest zgodna z opracowaniem Budżet czasu ludności w 2013 r. część II, zaś kolejne trzy nie są wyszczególnione w raportach GUS, ale warto podjąć próbę oceny ich wartości.

21. Zgodnie z dokumentem GUS Trwanie życia w 2014 r., dostępnym na: http://stat.gov.pl/files/gfx/portalinformacyjny/pl/defaultaktualnosci/5470/2/9/1/trwanie_zycia_w_2014r.pdf [dostęp: 21.08.2017], s. 15. 
aktywności i średnią stawkę godzinową za daną usługę w roku 2014, ${ }^{22}$ zaś w tab. 5. - wartości obecne rent, czyli wartości obecne kapitałów wymaganych do zakupu poszczególnych potrzeb zgodnie z przeciętnym wymiarem czasu poświęcanego na poszczególne aktywności w gospodarstwie domowym w Polsce.

Tablica 4. Lista substytutów - usług i godzinowych stawek za nie

\begin{tabular}{|c|l|c|c|}
\hline & \multicolumn{1}{|c|}{ Substytut } & $\begin{array}{c}\text { Kod grupy } \\
\text { zawodowej }\end{array}$ & $\begin{array}{c}\text { Stawka godzinowa } \\
\text { w pierwszym roku PLN/euro }\end{array}$ \\
\hline I & opiekunowie dziecięcy i asystenci nauczycieli & 531 & $11,95 / 2,91$ \\
\hline II & kucharze & 512 & $12,14 / 2,96$ \\
\hline III & pomoce i sprzątaczki domowe, biurowe i hotelowe & 911 & $11,67 / 2,85$ \\
\hline IV & rolnicy, ogrodnicy, leśnicy i rybacy & 6 & $14,35 / 3,5$ \\
\hline V & $\begin{array}{l}\text { malarze, pracownicy czyszczący konstrukcje budowlane } \\
\text { i pokrewni }\end{array}$ & 713 & $17,30 / 4,22$ \\
\hline VI & inni specjaliści nauczania i wychowania & 235 & $33,37 / 8,14$ \\
\hline
\end{tabular}

Źródło: oprac. własne na podst. Struktura wynagrodzeń według zawodów w październiku 2014 r.

Tablica 5. Wartości obecne kapitałów potrzebnych na zakup poszczególnych potrzeb (w PLN]

\begin{tabular}{|c|c|c|c|c|}
\hline & 4 lata & kolejne 11 lat & kolejne 18 lat & kolejne 9 lat \\
\hline I & 35654,76 & 57922,07 & 189981,949 & 96027,089 \\
\hline II & 14656,45 & 51781,84 & 105785,672 & 74829,182 \\
\hline III & 40891,37 & 142402,13 & 296956,964 & 191299,01 \\
\hline IV & 22982,73 & 83292,06 & 209846,427 & 140831,35 \\
\hline V & 58438,72 & 175463,88 & 325954,49 & 147345,52 \\
\hline VI & 72435,43 & 228061,23 & 258299,159 & 121806,44 \\
\hline
\end{tabular}

Źródło: oprac. własne.

Łącznie wartość obecna kapitału potrzebnego na zakup tych pierwszych sześciu składowych, wyznaczonych na podstawie wartości obecnej renty pewnej 42-letniej, to: $\mathrm{PV}_{\mathrm{I}-\mathrm{VI}}=3.142 .945,92 \mathrm{PLN}$ $=766.572$ euro.

Zaprezentowane dotychczas obliczenia oparto na liczbie godzin zgodnie z opracowaniem GUS, pozostałe punkty od VII do XI nie są ujęte w opracowaniu GUS, wymagane są zatem przy ich kalkulacji dodatkowe założenia.

\section{Ad. VII. Odrabianie lekcji z dziećmi}

W przypadku tej straty substytutem są korepetycje. Należy zatem ustalić, ile czasu dziennie rodzic spędzał z dziećmi przy odrabianiu lekcji. Na użytek przykładu poczyniono założenie, że ojciec odrabia lekcje z dziećmi 3 godziny tygodniowo, a rok szkolny to 40 tygodni. Ze względu na wiek córki, dopiero od 4. roku renty uwzględniona jest dla niej pomoc ojca w lekcjach. Przyjęto, że pomoc

22. Zgodnie z danymi GUS zamieszczonymi w raporcie Struktura wynagrodzeń według zawodów w październiku 2014 r., dostępnym na stronie: http://stat.gov.pl/obszary-tematyczne/rynek-pracy/pracujacy-zatrudnieni-wynagrodzenia-koszty-pracy/struktura-wynagrodzen-wedlug-zawodow-w-pazdzierniku-2014-r-,4,7.html 
rodzica jest niezbędna aż do końca nauki, tj. do 18. roku życia każdego z dzieci. Będzie to zatem renta pewna 16-letnia. W pierwszych 3 latach od wypadku ojciec odrabiałby lekcje z synem przez 120 godzin rocznie, od 4. roku pracowałby z dwójką dzieci, czyli spędzał na tym 240 godzin rocznie, a ostatnie 3 lata to ponownie praca tylko z jednym dzieckiem czyli wymiar 120 godzin rocznie Za stawkę godzinowa przyjęto kwotę z tab. 4. odpowiadającą zawodowi „opiekunowie dziecięcy i asystenci nauczycieli" kod 531, tj. kwotę 11,95 PLN². Uwzględniając wcześniejsze założenia co do indeksacji i dyskontowania, wartość obecna kapitału wyliczamy: $\mathrm{PV}_{\mathrm{VII}}=45.429,79 \mathrm{PLN}=$ 11.080 euro.

\section{Ad. VIII. Transport dzieci do szkoły}

Należy ustalić, jaka jest odległość od miejsca zamieszkania do szkoły. Rozsądne wydaje się przyjęcie uniwersalnego założenia, że dzieci byłyby odwożone przez rodzica do szkoły do 15. roku życia (tj. obecnie do ukończenia nauki w gimnazjum). A jeśli znany jest model samochodu, to za przejazd 1 km można przyjąć stawkę ryczałtową zgodnie z rozporządzeniem Ministra Infrastruktury²4.

Na użytek przykładu przyjmijmy, że odległość do szkoły wynosi 4 km i nie zmieni się ona, gdy dzieci zmienią szkołę. Ponadto przyjmijmy, że dzieci chodzą do tej samej podstawówki, zatem w 4. i 5. roku (kiedy drugie z dzieci pójdzie do szkoły) rodzic wciąż będzie wykonywał jeden kurs do szkoły i jeden ze szkoły. Później od 6. roku (kiedy starsze dziecko zmieni szkołę) przez 4 lata rodzic wykona podwójną liczbę kursów, a następnie przez 4 lata już tylko po jednym w każdą stronę. Przeciętnie rok szkolny to 40 tygodni. Zatem przyjęto, że przez 13 lat rocznie zostanie przejechane po 320 km, z wyłączeniem lat 6-9, kiedy to odległość ta będzie większa w związku ze zmiana szkoły przez jedno z dzieci i wyniesie $640 \mathrm{~km}$. Założono, że rodzina posiada pojazd o pojemności silnika do $900 \mathrm{~cm}^{3}$. Zgodnie z rozporządzeniem ryczałt za $1 \mathrm{~km}$ to 0,5214 zł.

Przyjmując indeksację stawki kilometrażowej o stopę inflacji na poziomie 2,53\% i dyskonto po stopie 1,44\%, wartość obecna kapitału na tę usługę $P V_{\text {VIII }}=3029,98$ PLN = 739 euro. Oczywiście należy mieć na uwadze, że jest to kwota niedoszacowana, ponieważ w sytuacji powierzenia transportu dzieci do szkoły stawka byłaby dużo wyższa.

\section{Ad. IX Prace związane z zawodem, wykonywane nieodpłatnie dla gospodarstwa domowego (w przykładzie naprawy samochodu)}

I w tym przypadku nie ma danych dotyczących średniego wymiaru świadczenia nieodpłatnie dla gospodarstwa domowego prac związanych z wykonywanym zawodem. W przykładzie przyjęto, że rodzina ma dwa samochody naprawiane dotychczas przez zmarłego. Ponieważ wysoce prawdopodobne jest, że rodzina sprzeda jeden z samochodów, to przyjęto, iż poszkodowany naprawiałby jedno auto w wymiarze 2 godzin w tygodniu czyli rocznie - 104 godziny. Wynagrodzenie

23. Kwota ta znacznie odbiega od realnych stawek za korepetycje. Za godzinę korepetycji np. z matematyki we Wrocławiu rodzice płacą średnio 40 PLN. Niemniej przyjęto średnią wartość z danych ogólnopolskich.

24. Rozporzadzenie Ministra Infrastruktury z 25 marca 2002 r. w sprawie warunków ustalania oraz sposobu dokonywania zwrotu kosztów używania do celów służbowych samochodów osobowych, motocykli i motorowerów niebędących własnością pracodawcy, Dz. U. 2002, nr 27 poz. 271: http://isap.sejm.gov.pl/DetailsS ervlet?id=WDU20020270271 [dostęp: 22.08.2017]. 
mechanika przyjęto za GUS - stawka godzinowa za pracę mechaników maszyn i innych urządzeń (kod 723) - 21,43 PLN. Przyjęto założenie, że poszkodowany naprawiałby auto do 60. roku życia, czyli posłużono się w kalkulacji 25-letnią renta pewną. Wartość obecna wyniosła $\mathrm{PV}_{\mathrm{IX}}=$ 63 530,93 PLN = 15.495 euro.

\section{Ad. X. Ubezpieczenie zdrowotne}

W sytuacji, kiedy po śmierci rodzina jest zmuszona samodzielnie ponieść koszt ubezpieczenia zdrowotnego, również ten koszt zalicza się do zwiększonych potrzeb. Przyjęto założenie, że do ubezpieczenia zostanie zgłoszona żona (przyjęto za danymi GUS ${ }^{25}$, że żona przeżyje 82 lata, a zatem kalkulacja zostanie oparta na rencie pewnej 30-letniej]. Ponadto przyjęto, że dzieci będą ubezpieczone w ramach ubezpieczenia matki. Wysokość składki na ubezpieczenie zdrowotne wynosi $9 \%$ podstawy jej wymiaru. Dla osób samodzielnie zgłaszających się do ubezpieczenia podstawę stanowi przeciętne miesięczne wynagrodzenie w sektorze przedsiębiorstw. Składka na dobrowolne ubezpieczenie zdrowotne w miesiącach kwiecień, maj i czerwiec 2017 roku wynosiła po 395,15 zł. Taką wielkość miesięczną przyjęto dla pierwszego roku [dwunastokrotność, tj. w pierwszym roku 4 741,80 PLN), a dla kolejnych lat wielkość tę zindeksowano o stopę inflacji. Wartość obecna kapitału w tym przypadku wynosi PVXI = 166 811,55 PLN = 40686 euro.

Łącząc wszystkie dziesięć zdiagnozowanych i wycenionych składowych potrzebnego kapitału, otrzymano: PV = 3421 748,17 PLN = 834572 euro. Skoro średnie wynagrodzenie $w$ gospodarce ${ }^{26}$ w Polsce w pierwszym kwartale 2017 roku wyniosło 4 353,55, to PV kapitału odszkodowawczego za znaczne pogorszenie sytuacji życiowej stanowi wartość 65 razy wyższą od rocznego wynagrodzenia na średnim poziomie $w$ gospodarce $w$ Polsce.

Wskazane powyżej kalkulacje nie uwzględniają mierzalnych kosztów związanych z leczeniem skutków psychicznych traumatycznego zdarzenia, jakim jest śmierć w rodzinie, tj. kosztów terapii i leków.

Należy podkreślić, że jest też wiele niemierzalnych aspektów, które powinno uwzględnić się w pomiarze skutków szkody osobowej. Ale w przypadku ustalania wysokości rekompensaty za nie, winno się je uwzględniać w innej części, tj. w zadośćuczynieniu za ból i cierpienie. Podstawa jest tu ziszczenie się ryzyka pogorszenia sytuacji życiowej oraz obniżenia jakości życia. Realizuje się ono przykładowo przez:

- zerwanie więzi rodzinnych,

- ryzyko obniżenia „kasty”,

- ryzyko utarty pracy przez pozostałego przy życiu rodzica (np. z powodu większego obciążenia obowiązkami, gorszego postrzegania przez pracodawców rodziców samotnie wychowujących dzieci),

- ryzyko utraty kontaktów środowiskowych,

- ryzyko zmniejszonej samooceny osieroconych dzieci,

- zmniejszenie zakresu czasu wolnego na samorozwój czy odpoczynek i regenerację,

- ryzyko zmiany miejsca zamieszkania.

25. GUS, Trwanie ..., op. cit.

26. Za http://stat.gov.pl/sygnalne/komunikaty-i-obwieszczenia/lista-komunikatow-i-obwieszczen/komunikat-w-sprawie-przecietnego-wynagrodzenia-w-i-kwartale-2017-roku,271,16.html [dostęp: 25.07.2017]. 


\section{Wnioski}

Powyższe rozważania pokazują, że strata materialna wynikła ze szkody osobowej ma znaczące skutki dla gospodarstwa domowego. Powstała luka przez fakt utracenia dochodu to strata rzędu 30-krotności rocznego wynagrodzenia osoby zmarłej. Również znaczącym problemem jest strata polegająca na utraconym wkładzie osobowym skutkujacca znaczym pogorszeniem sytuacji życiowej. Na utracony wkład osobowy, jak pokazano to w artykule, składają się elementy mierzalne i możliwe do wycenienia, jak i niemierzalne i niemożliwe do wycenienia. Pierwsze wyrazić można cenami usług, które trzeba kupić, aby zastapić wkład osobowy osoby zmarłej. Zaś te drugie związane z relacjami, bólem i cierpieniem - nie mają ceny i substytutów na rynku i powinny być wynagrodzone rodzinie w części odszkodowania zwanej „zadośćuczynieniem”. W omówionym przykładzie widać, że wartość obecna tej szkody może być jeszcze wyższa od szkody związanej z utraconymi dochodami.

Można wskazać kilka źródeł pokrycia osobowej szkody majątkowej. Mogą to być:

- ubezpieczenie społeczne (w Polsce jest to np. renta rodzinna dla członków rodziny zmarłego; jest ona regulowana przepisami²? , zgodnie z którymi prawa do niej nie mają przykładowo konkubenci);

- Środki od sprawcy szkody (pracodawcy, kierowcy, popełniającego błąd medyczny czy też innego winnego szkody);

- Środki z polisy ubezpieczenia OC sprawcy (część tych ubezpieczeń jest obowiązkowa; warto mieć też na uwadze problem wystarczalności sum gwarancyjnych z takich ubezpieczeń ${ }^{28}$ );

- Środki własne i z pożyczek od członków rodziny i znajomych;

- środki fundacji i zbiórek pieniężnych.

Jednak dyskusja nad dostępnością i wystarczalnością tych źródeł to materiał na kolejne badanie. Warto podkreślić, że wśród wskazanych źródeł finansowania to właśnie ubezpieczenia odpowiedzialności cywilnej są najpowszechniejsze. Dlatego tak ważne jest, aby suma gwarancyjna dawała realną ochronę ubezpieczonemu i przeniosła na ubezpieczyciela ciężar finansowania skutków szkody. Jest to ważne zwłaszcza w przypadku ubezpieczeń obowiązkowych, aby zminimalizować hazard moralny związany z kupowaniem ubezpieczenia o niedostatecznie niskiej sumie, aby tylko spełnić obowiązek jego posiadania. Stąd też dla przykładu Komisja Europejska dostosowuje wysokość minimalnych sum gwarancyjnych dla ubezpieczeń odpowiedzialności cywilnej posiadaczy pojazdów mechanicznych na podstawie Dyrektywy 2009/103/EC ${ }^{29}$ ws. ubezpieczenia

27. Art. 67 ustawy z dnia 17 grudnia 1998 r. o emeryturach i rentach z Funduszu Ubezpieczeń Społecznych, Dz. U. 2016, poz. 2036.

28. Więcej na temat wystarczalności minimalnych sum gwaracyjnych w: A. Jędrzychowska, E. Poprawska, W. Ronka-Chmielowiec, The sufficiency of the minimum amounts in compulsory liability insurance to cover personal injury claims - based on motor third party liability insurance and medical liability insurance, „Wiadomości Ubezpieczeniowe" 2015, nr 4, s. 79-102; A. Jędrzychowska, E. Poprawska, Analysis of the Problem of Determining Loss of Income and Sources for their Financing. The Case of Personal Injuries Caused in Traffic Accidents, „Transformations in Business \& Economics” 2016, Vol: 15, No: 2A (38A), s. 329-353; A. Jędrzychowska, E. Poprawska, Is the minimum amount of coverage from motor third party liability insurance enough to cover personal injuries?, „Journal of Risk Management in Financial Institutions” 2016, No 1/2, s. 125-141.

29. http://eur-lex.europa.eu/eli/dir/2009/103/oj [dostęp: 25.07.2017]. 
odpowiedzialności cywilnej za szkody powstałe w związku z ruchem pojazdów mechanicznych i obowiązku ubezpieczenia takiej odpowiedzialności. Zgodnie z art. 9 ust. 2 jednym z zadań Komisji Europejskiej jest waloryzowanie kwot określonych w Dyrektywie zgodnie z aktualną stopą inflacji. Waloryzacja taka odbywa się raz na 5 lat. Od 2017 roku wysokość sum gwarancyjnych w obowiązkowych ubezpieczeniach komunikacyjnych OC została zwiększona. W przypadku szkody na osobie minimalną sumę gwarancyjną podniesiono do 1220000 euro na jednego poszkodowanego oraz do 6070000 euro na jedno zdarzenie drogowe.

\section{Wykaz źródeł}

Błaszczak-Przybycińska I., Produkcja gospodarstw domowych jako czynnik dochodotwórczy, „Monografie i Opracowania” 2008, nr 553, Oficyna Wydawnicza SGH, Warszawa 2008.

Bowers N.L., Gerber H.U., Hickman J.C., Jones D.A., Nesbitt C.J., Actuarial Mathematics, The Society of Actuaries, Itasca, IL 1986.

Budżet czasu ludności w 2013 r. Część II. GUS, http://stat.gov.pl/obszary-tematyczne/warunki-zycia/dochody-wydatki-i-warunki-zycia-ludnosci/budzet-czasu-ludnosci-w-2013-r-czesc-ii-wraz-z-czescia-i,19,2.html [dostęp: 21.06.2017].

Carmignani A., Giacomelli S., Too many lawyers? Litigation in Italian civil courts, „Temi di Discussione” February 2010, nr 745, http://www.astrid-online.it/--giustizi/GIUSTIZIA-/Studi--ric/determinanti-litigiosit--Bdl.pdf. [dostęp: 17.06.2017].

Current trends in bodily injury claims in MTPL insurance: 2010-2015: promotor 2016 report, Monkiewicz J., Monkiewicz M. [red.], ProMotor, Warszawa 2016.

Czachórski W., Zobowiqzania. Zarys wykładu, PWN, Warszawa 1994.

Enz R., Holzheu T., The economics of liability losses - insuring the moving target, „Sigma” 2004, nr 6. European Motor Insurance Markets. Addendum, June 2016, https://www.insuranceeurope.eu/ european-motor-insurance-markets-addendum [dostęp: 21.06.2017].

Furedi F., Courting Mistrust: The hidden growth of a culture of litigation in Britain; Centre for Policy Studies, London 1999

Green L., The study and teaching of tort law, „Texas Law Review” 1955, vol. 34.

Holzheu T., Lechner R., Commercial liability: a challenge for businesses and their insurers, „Sigma” 2009, nr 5.

Jaździk-Osmólska A., Wycena kosztów wypadków i kolizji drogowych na sieci dróg w Polsce na koniec roku 2015, z wyodrębnieniem średnich kosztów społeczno-ekonomicznych wypadków na transeuropejskiej sieci transportowej, Krajowa Rada Bezpieczeństwa Ruchu Drogowego, Warszawa 2016.

Jędrzychowska A., Poprawska E., Analysis of the Problem of Determining Loss of Income and Sources for their Financing. The Case of Personal Injuries Caused in Traffic Accidents, „Transformations in Business \& Economics" 2016, Vol: 15, No: 2A (38A).

Jędrzychowska A., Poprawska E., Is the minimum amount of coverage from motor third party liability insurance enough to cover personal injuries?, „Journal of Risk Management in Financial Institutions" 2016, No 1/2. 
Jędrzychowska A., Poprawska E., Ronka-Chmielowiec W., The sufficiency of the minimum amounts in compulsory liability insurance to cover personal injury claims - based on motor third party liability insurance and medical liability insurance, „Wiadomości Ubezpieczeniowe” 2015, nr 4. Karaś T., Uwagi na temat pojęcia „szkoda” w amerykańskiej teorii prawa, „Studia luridica” 2007, XLVII. Kwiecień I., Ekonomiczna analiza dochodzenia roszczeń o zadośćuczynienie za szkody na osobie z ubezpieczeń odpowiedzialności cywilnej, Wydawnictwo Uniwersytetu Ekonomicznego we Wrocławiu, Wrocław 2015.

Leimbacher U. et al., The globalisation of collective redress: Consequences for the insurance industry, Swiss Re Raport 2009.

Lowe J. [red.], The cost of damages culture, Working Party of The Actuaries Society, 2002 www. actuaries.org.uk/_data/assets/pdf_file/0007/.../Lowe.pdf [dostęp: 17.06.2017].

Marszałek M., Rachunek produkcji domowej w Polsce w koncepcji systemu statystyki społecznej, Oficyna Wydawnicza SGH, Warszawa 2015.

Mayr D., Severe Bodily Injury Claims In Europe - Developments And Trends; Munich Re, 2011, http:// piu.org.pl/public/upload/ibrowser/Munich\%20Re.pdf [17.06.2017)

Motor Insurance and Reinsurance. Current Issues and Future Trends, Scor Global P\&C, „Focus” February 2015.

Motor Third Party Liability: Analysis of Serious Bodily Injury compensation from a European perspective, Scoor Global P\&C, June 2013, https://www.scor.com/PandC_docs/SCORNL_DommagesCorpo EN_072013b.PDF [dostęp: 17.06.2017].

Narita S., Product liability claims in Europe; Swiss Reinsurance Company Ltd., Zurich 1997.

Rozporządzenie Ministra Infrastruktury z 25 marca 2002 r. w sprawie warunków ustalania oraz sposobu dokonywania zwrotu kosztów używania do celów służbowych samochodów osobowych, motocykli i motorowerów niebędących własnościa pracodawcy, Dz. U., 2002 nr 27 poz. 271.

Schmidt J.T., Factors Likely to Influence Tort Litigation in the European Union, „The Geneva Papers on Risk and Insurance - Issues and Practice" 2009, nr 31, s. 304-313.

Struktura wynagrodzeń według zawodów w październiku 2014 r., GUS, http://stat.gov.pl/obszary-tematyczne/rynek-pracy/pracujacy-zatrudnieni-wynagrodzenia-koszty-pracy/struktura-wynagrodzen-wedlug-zawodow-w-pazdzierniku-2014-r-,4,7.html [dostęp: 20.06.2017].

Szkody osobowe kompensowane z ubezpieczenia komunikacyjnego OC. Analiza rynku, Kwiecień I. [red.], Poltext, Warszawa 2011.

Szkody osobowe z OC komunikacyjnego. W poszukiwaniu nowych rozwiqzań, Monkiewicz J., Monkiewicz M. [red.], Poltext, Warszawa 2017

Tomczuk M., Wycena wartości prac domowych w rodzinach w Polsce, [w:] Instytucja rodziny wczoraj i dziś. Perspektywa interdyscyplinarna. Tom. 1. Między prawem i rynkiem, Stepkowska K., Stepkowska J. [red], Politechnika Lubelska, Lublin 2012.

Trwanie życia w 2014 r., GUS, http://stat.gov.pl/files/gfx/portalinformacyjny/pl/defaultaktualnosci/5470/2/9/1/trwanie_zycia_w_2014r.pdf [dostęp: 20.06.2017].

Ustawa o emeryturach i rentach z Funduszu Ubezpieczeń Społecznych, z dnia 17 grudnia $1998 \mathrm{r}$. Wałachowska M., Wynagradzanie szkód deliktowych doznanych przez pośrednio poszkodowanych, LexisNexis, Warszawa 2014.

Wigmore K.H., A general analysis of tort relations, „Harvard Law Review” 1895, vol. 8.

Yang J., Reeves S., Observations on European Motor Body Injury insurance, 2013, http://www.actuaries.asn.au/Library/Events/ACS/2013/ReevesYangObservations.pdf [dostęp: 17.06.201?]. 
Zadośćuczynienie po nowelizacji art. 446 Kodeksu cywilnego na tle doświadczeń europejskich „Wiadomości Ubezpieczeniowe” 2010, nr 1 - specjalny, https://piu.org.pl/public/upload/ibrowser/zadoscuczynienie_WU.pdf [dostęp: 25.07.2017].

\section{Compensation for household members affected by the death of breadwinner}

Article shows the size of the budget gap that arises in the household after the death of one of its members, who was the breadwinner of the family. This personal injury has two types of consequences.

The first one is lost income. One source of funding this gap could be for example annuity for indirect victims. In many $\varepsilon U$ countries, people who are members of the household of the deceased are considered to be affected as a result of his death. Indirectly affected will be the family members and relatives of the deceased (spouse, parent, child, sibling, and cohabitant). This person who is guilty of death should pay compensation to the family members of the deceased.

The second one is the lost personal contribution to the household. In this part it is necessary to know the current value (valuation) of the capital, which will allow you to buy out of the household services that will replace the lost personal contribution. This elements is connected with compensation for deterioration of living conditions.

The paper will be presented to the study of literature as an introduction to the issues. The study will be prepared for selected $E U$ countries. Article is part of a broader study of the author of the material consequences of personal injury and sources of their financing.

Keywords: indirectly injured, personal injuries, compensation, present value of annuity.

DR ANNA JĘDRZYCHOWSKA - Katedra Ubezpieczeń, Uniwersytet Ekonomiczny we Wrocławiu. 
